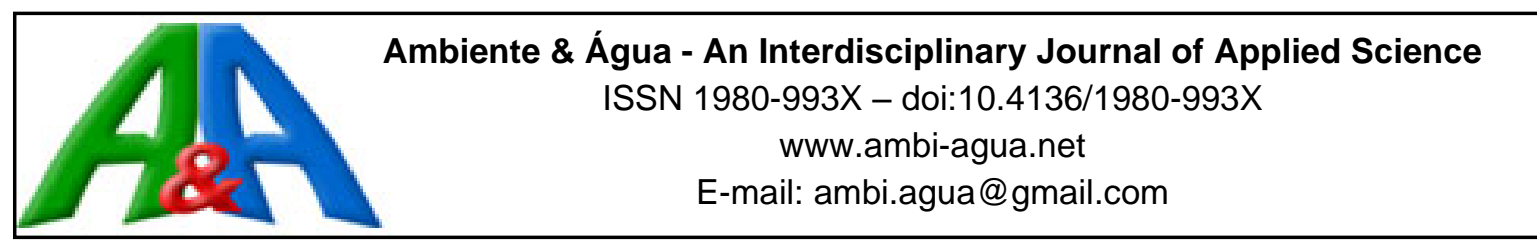

\title{
Exposure to agricultural pesticides and use of personal protection equipment by small-scale farmers in a municipality of Minas Gerais, Brazil
}

ARTICLES doi:10.4136/ambi-agua.2542

Received: 13 Sep. 2020; Accepted: 17 Oct. 2020

\begin{abstract}
Júlio César Barbosa da Silva ${ }^{1}$; Felipe Lima Dipe ${ }^{1}$; Camila dos Santos Leite $^{2}$; Ana Aparecida da Silva Almeida ${ }^{3 *(D)}$; Oscar César Pires ${ }^{3(D)}$
\end{abstract}

\footnotetext{
${ }^{1}$ Departamento de Medicina. Universidade de Taubaté (UNITAU), Avenida Tiradentes, n500, CEP: 12030-180, Taubaté, SP, Brazil. E-mail: julio_c.barbosa@hotmail.com, felipedipe@gmail.com

${ }^{2}$ Programa de Pós-Graduação em Ciências da Saúde. Universidade São Francisco (USF), Avenida São Francisco de Assis, n²18, CEP: 12961-900, Bragança Paulista, SP, Brazil. E-mail: camilayantony@gmail.com

${ }^{3}$ Programa de Pós-Graduação em Ciências Ambientais (PPGCA). Universidade de Taubaté (UNITAU), Estrada Municipal Doutor José Luiz Cembranelli, n5000, CEP: 12081-010, Taubaté, SP, Brazil.

E-mail: oscarpires50@gmail.com

*Corresponding author. E-mail: anaparecida.almeida@gmail.com
}

\begin{abstract}
The use of agricultural pesticides in Brazil has significantly increased during recent decades, especially due to the competition between the internal Brazilian market and that for exports. Pesticides are among the most important risk factors for the health of the general population, especially workers, and the environment, resulting in a scenario of increased public spending on health and social damage due to pollution by such chemicals, with emphasis on organophosphates and carbamates. When these substances are managed incorrectly, such as when personal protection equipment (PPE) is not used, or when they are inadequately discarded without adhering to sanitary disposal guidelines, they can cause pollution and short- and longterm damage to health. This paper therefore surveys the knowledge base of small-scale farmers with respect to exposure to agrochemicals and the importance of use of PPEs. This qualitative and transversal study relied upon the voluntary participation of 64 residents of a rural area. The study was initiated after having received approval of the Committee for Ethics in Research, and after the participants signed an informed consent form. A questionnaire was given to the participants which used multiple choice and open-ended questions. All the participants stated that they use fertilizers and other agrochemicals, and that they do not use or only sporadically use PPEs. All the participants related that they have not had access to specialized technical assistance to help with proper use of agrochemical products, and that they store these products inadequately in their house or in other inappropriate places. These small-scale farmers do not use PPEs and underestimate the damage to their health and that of their family that can be caused by improper use of agrochemicals, and also demonstrate a lack of technical knowledge with respect to adequate management of these products.
\end{abstract}

Keywords: agricultural pesticides, occupational health, organophosphorus, rural work. 


\section{Exposição a agrotóxicos e o uso de equipamentos de proteção pessoal por pequenos agricultores em um município de Minas Gerais, Brasil}

\section{RESUMO}

O uso de defensivos agrícolas, os agrotóxicos, no Brasil tem aumentado significativamente nas últimas décadas, sobretudo, pela necessidade de competição entre o mercado interno brasileiro e a exportação. Os agrotóxicos estão entre os mais importantes fatores de risco à saúde da população geral, especialmente aos trabalhadores, e ao meio ambiente, resultando em um cenário de aumento de gastos públicos com saúde e prejuízo social devido a intoxicações por tais produtos químicos com destaque para os organosfosforados e carbamatos. Essas substâncias quando usadas de forma irregular, sem EPIs ou descartadas de forma inadequada ao que é estipulado pela vigilância sanitária provocam intoxicações que levam a danos de curto a longo prazo. Com o objetivo de estabelecer o conhecimento de agricultores familiares sobre a exposição a agrotóxicos e importância do uso de EPIs, este trabalho realizou um estudo transversal, qualitativo, com participação, por conveniência, de 64 moradores da zona rural. A pesquisa teve início após aprovação do Comitê de Ética em Pesquisas com Seres Humanos, assinatura do termo de consentimento livre e esclarecido e constou da aplicação de um questionário com questões de múltipla escolha e dissertativas. Participaram do estudo 64 agricultores familiares, sendo 51 homens e 13 mulheres, com idade variando entre 18 e 65 anos. Todos os pesquisados referem fazer uso de agrotóxicos e não utilizar ou utilizar esporadicamente os EPIs. Todos os entrevistados referem não ter assistência especializada para orientação sobre o uso dos produtos, inclusive os armazenam de forma inadequada em casa ou em locais inapropriados. Assim, foi possível concluir que os agricultores familiares pesquisados subestimam os danos sobre si e sua família e demonstram falta de conhecimento técnico referente ao manejo adequado desses produtos.

Palavras-chave: defensivos agrícolas, exposição ocupacional, organofosforados, trabalho rural.

\section{INTRODUCTION}

Agricultural pesticides, agrochemicals, are fundamentally relevant to the agricultural development model in Brazil, which is the largest consumer of these products in the world (Brasil, 2019). The federal government, through a diversity of agencies, is responsible for regulation of agrochemicals based on the law $n^{\circ} 7.802 / 89$ and by the decree $n^{\circ} 4074 / 02$ (Brasil, 2002; 1989; Nascimento and Melnyk, 2016) which establishes rules for use, storage, and processing of agrochemical products. Also known as "agricultural defensive agents" are products used in rural agricultural areas and even in cities as a function of public health actions, like several insecticides for elimination of mosquitoes.

Among the entire population of Brazil, agricultural producers are the most exposed to agrochemicals, either through direct contact, frequency of use, or even through inadequate use by not using personal protection equipment (PPE). For this reason, these farmers represent the portion of the population that is most at risk for suffering severe intoxication through contact with these products, and also to develop cumulative effects (Hungaro et al., 2015; Viero et al., 2016).

A study conducted examining rural farmers who were hospital patients presenting neoplasm related that the use of agrochemicals without the use of PPEs was common among these patients, and that there was predominance of neoplasms in the digestive tract, followed by cancer of the prostate and uterus, respectively (Silva et al., 2016).

These neoplasm cases were most common in patients older than 61 years with just 1 to 4 years of formal education (Silva et al., 2016). Additionally, lymphomas have been associated 
with the use of agrochemicals (Costa et al., 2017).

It is not just chronic diseases that are related to the use of these products, but severe intoxication is also common, which can result in inhibition of acetylcholinesterase resulting in cholinergic hyperstimulation (Cavalcanti et al., 2016, which can cause diarrhea, vomiting, and even death (Hungaro et al., 2015). For this reason, studies that aim to profile workers that are affected by the use of agrochemicals, as well as the consequences resulting from their inadequate use are relevant and can reveal the portion of the population that needs attention and orientation from the government and other responsible entities.

Despite the relative leadership of Brazilian industry compared to other countries in South America, the gross domestic product (GDP) of Brazil is sustained primarily by agribusiness. At the heart of the agricultural industry scenario is small-scale, or family-based agriculture. In order to compete with large agribusiness companies, the small-scale producer must make a great effort to produce more in smaller areas, and for this reason incorporates the use of agrochemicals to increase production and combat pests. Many of these products are based on organophosphates, carbamates, and pyrethroids (Nascimento and Melnyk, 2016), among other substances which are associated with severe intoxication, development of chronic diseases such as cancer, cardiovascular and dermatological diseases, and in some cases even death, especially when PPEs are not used. This situation generates socioeconomic costs for families as well as for the state, thus increasing expenditures related to health care, expensive medications, and hospitalizations. In light of the dimension of the social problems that intoxication by agrochemicals can cause for the public health system, scientific studies are needed to evaluate the knowledge of the population with respect to these products and the problems associated with their inadequate use, such as chronic diseases. In this way, science can collaborate with strategic planning and actions aimed at creating public policies to control and prevent diseases associated with inadequate use of agrochemicals.

The most used agricultural pesticides are:

a) Organochlorates: among the first agrochemicals to be developed; have chlorine atoms linked to a carbon chain, which offers relative stability and low reactivity with other substances. On the other hand, this stability makes this class of compounds have low water solubility but makes them highly soluble in organic solvents. Their high chemical stability makes decomposition of these compounds difficult, and therefore they have high potential to accumulate in tissues of living beings (Nascimento and Melnyk, 2016).

b) Organophosphates: are used in a large range of crops and are responsible for many cases of intoxication, especially due to their transcutaneous absorptive capacity. Oral absorption and inhalation are responsible for a lower proportion of cases of intoxication (Nascimento and Melnyk, 2016). These solubility characteristics are principally due to bonds with phosphorus atoms in their molecules which confer high absorption oral, dermal, and respiratory rates. They are irreversible inhibitors of cholinesterase, but do not accumulate in the organism and are easily degraded. Intoxication can cause bradycardia, arterial hypertension, diarrhea, muscular fasciculation, respiratory insufficiency, convulsions, miosis, drooling, and there is always a great risk of death (Hungaro et al., 2015) and development of oncological diseases (Costa et al., 2017).

c) Carbamates: these are also inhibitors of cholinesterases; however, this inhibition is reversible due to a weak bond with the enzyme (Hungaro et al., 2015). Another aggravating factor is their relationship with congenital deformities, such as spina bifida (Dutra and Ferreira, 2017) and the development of non-Hodgkin's lymphoma (Costa et al., 2017). This class of agrochemicals has the advantage of being rapidly decomposed in aquatic environments (Nascimento and Melnyk, 2016).

d) Pyrethroids: These are currently among the most utilized agrochemicals (Nascimento and Melnyk, 2016), and are produced through milling of flowers and plants of the family 
compositae (Hungaro et al., 2015; Nascimento and Melnyk, 2016) Intoxication symptoms include manifestation of hypersensibility such as erythema, headaches, asthenia, blurred vision and diplopia, neurological and cardiovascular disturbances (Cerqueira et al., 2010). These are used in a wide range of crops, especially for vegetables (Araújo et al., 2007)

e) Dithiocarbamates: These are used as fungicides (Delgado and Paumgartten, 2004) and are subdivided into dimethyldithiocarbamates (DMDC) and ethylene bis-dithiocarbamates (EBDCs). In Brazil, the volume of EBDCs applied is more than $40 \%$ of the total quantity of fungicides used in the country. This subclass contains mancozebe, a popular fungicide of toxicological Class III, which is considered moderately toxic. This subclass contains metabolites that have the capacity to cause tumors in the thyroid gland and liver in animals (Lemes et al., 2005).

f) Glyphosate: organophosphate herbicide apparently associated with lymphoma of B cells (Schinasi et al., 2014). The volume of application of herbicides that possess this substance in their formulas increased 100 times since its introduction in crop cultures in the 1970s, which has apparently greatly contributed to the appearance of glyphosate-resistant weeds (Myers et al., 2016).

g) Paraquat: A herbicide that is a quaternary compound of ammonium and soluble in water. It is toxic to human beings, and a laboratory study has shown that experimental intoxication in rats stimulates neurodegenerative mechanisms similar to those of Parkinson's disease (Ossowska et al., 2006).

h) 2,4 dichlorophenoxyacetic acid (2,4 D): A herbicide used for weed control, principally in grain crops and grass (Rodrigues and Serra, 1996). Its action in plants mimics the plant hormone auxin, and it has well-known carcinogenic effects in humans (Vieira et al., 1999).

It is estimated that, between the years 2012 and 2016, there were more than 13.7 thousand cases of intoxication by agrochemicals registered nationally. These cases were more prevalent in men $(62 \% ; n=6933)$ than in women $(37 \% ; n=4126)$. A total of $23 \%(n=2610)$ were workers who suffered accidents during work, $28 \%(\mathrm{n}=3231)$ were isolated, meaning they effected just one single worker, and $0.7 \%(\mathrm{n}=82)$ of these cases involved two or more workers. Another important aspect of these data is that more than 13,000 of these cases $(55 \% ; n=7584)$ correspond to the age range of 20 to 59 years, which represents the portion of the population that is most economically active, which aggravates socioeconomic impacts. A total of $24 \%$ (n $=3306)$ were people younger than 18 years, with $56 \%(n=1863)$ of these younger than 10 . This last result demonstrates that even the youngest members of the population are at risk for intoxication from agrochemicals and even due to their young age have a high risk of developing chronic diseases over a longer period of time. Furthermore, of the total number of registered cases $55 \%(\mathrm{n}=7536)$ were curable, $1 \%(\mathrm{n}=72)$ had some type of permanent after-effect, and $3 \%(\mathrm{n}=384)$ lead to death. Of these deaths, $74 \%(\mathrm{n}=283)$ were between 20 and 59 years, $64 \%$ $(\mathrm{n}=243)$ were men, $36 \%(\mathrm{n}=136)$ were women, and for $0.8 \%(\mathrm{n}=3)$ this information was not included in the notification (Sinitox, 2018).

In a similar study, there was also a predominance of cases of intoxication in men, with a range in age between 20 and 59 years, and 12\% of the investigated cases were under 10 years old (Hungaro et al., 2015).

This study surveyed the knowledge base of small-scale farmers with respect to exposure to agrochemicals and the importance of use of PPEs.

\section{MATERIAL AND METHODS}

This study has a qualitative, transversal design, with the voluntary participation of 64 residents of a rural area who are affiliated with an agricultural cooperative in the municipality of Paraisópolis, Minas Gerais (MG), Brazil, who responded to a questionnaire elaborated by 
the researchers of this study.

This study was initiated after approval by the Committee on Research and Ethics Involving Human Subjects (CEP/CONEP), under approval number 3.301.689. A questionnaire with 31 multiple-choice and open-ended questions was applied to residents of the rural zone, all of whom work in agriculture and had signed an informed consent form (TCLE).

The collected data were organized into age group, ethnicity, gender, education level, besides other relevant factors including information on application of agrochemicals, types of products used, knowledge about names of products, use of PPEs, locale where equipment is washed, contamination of the community water supply, types of crops, locale where empty containers are kept, and the return of empty containers to proper recycling entities, among others. All results were presented as percentages.

\section{RESULTS AND DISCUSSION}

A total of 64 small-scale farmers from the rural area of Paraisópolis - MG, Brazil participated in this study, divided into 51 men and 13 women.

Most of the participants have resided in their community since childhood and have always participated in family-based agricultural activities, which makes them ideal candidates to discuss their use and exposure to agricultural defensive agents. Ages for men varied between 18 and 65 , and for women the range was 23 to 46 years.

Among the men, 27 (53\%) declared themselves to be white, 18 (35\%) black, and $6(12 \%)$ brown; among the women, $6(46 \%)$ declared themselves to be white, $4(31 \%)$ black, and 3 $(23 \%)$ brown. With respect to education level, $1(0.2 \%)$ participant declared himself to be illiterate, $3(5 \%)$ had not completed grade school, 7 (11\%) had completed grade school, 17 (26.6\%) had not completed high school, and 36 (56.3\%) had completed high school. In relation to chronic diseases, 23 (36\%) stated they had one, and of these 14 had systemic arterial hypertension (HAS), 3 had diabetes mellitus (DM), 3 had chronic obstructive pulmonary disease (DPOC), 3 had hyperthyroidism, and 1 had asthma.

Among the interviewees, 14 reported a family history of cancer, with 7 (50\%) of these being a tumor of the gastrointestinal tract; skin cancer was reported by 4 participants $(28.5 \%)$. Among the participants, 18 (28\%) stated they were smokers, and 27 (31\%) regularly consumed alcoholic beverages.

Most of the participants stated that they had been working in agriculture since childhood, which suggests that there has been a potentially long period of exposure to agrochemicals with subsequent accumulative effects on health. Of the 64 interviewees, 19 (29\%) worked in another activity besides agriculture.

All the participants stated that they used fertilizers and agrochemicals, with the most-used products including thiamethoxam (neonicotinoid chemical group), lambda-cyhalothrin, alphacypermethrin and deltamethrin (pyrethroids), and cymoxanil, which contains acetamida and alkylenes dimethyldicarbamate group). Additionally, the participants related use of mancozebe, a fungicide of the dithiocarbamate group, and thiophanate-methyl, a fungicide of the benzimidazole group.

An important result in this study is that all participants (100\%) related that they do not routinely use PPEs or use them in an irregular manner, and that the utilized equipment, such as individual sprayers, are cleaned at the spraying site or in the farmer's home. In general, the interviewees related that they have at some time received orientation on how to use these materials, as well as about pertinent information on the packaging at the place of purchase. Furthermore, the respondents stated that they were unaware of any educational campaign about the use of PPEs.

Among the participants, $14(21 \%)$ related that they did not know what an intoxication is, and $60(93 \%)$ stated that they knew what one was and cited vomiting, diarrhea, and weakness 
as the principal symptoms. A total of $14(21 \%)$ people reported that they have suffered some degree of intoxication that required a visit to a hospital for treatment.

All the interviewees related that they did not have access to specialized technical assistance with use of agrochemicals at their place of work, that they inadequately store these products by keeping them in their houses or in other inappropriate places. Only 28 participants (43\%) related that they had received instruction on use of these products at the place of purchase.

Ten participants (15\%) burn the packages after use, which is contrary to the recommendation of ANVISA, which advocates return of empty containers to the place of purchase. All the interviewees stated that they use agrochemicals with sprayers and that there are no measures taken to prevent contamination after application. However, they stated that soil and water contamination is a serious problem, and 38 of the participants (59\%) ingest food and liquids during spraying operations.

This study showed that the small-scale farmers in this region of MG in general don't use PPEs when applying agrochemicals, and this finding reinforces results from the literature which show that this is also the case for Brazil in general (Viciana, 2012). This attitude is probably the most important risk factor associated with intoxication by agrochemicals, and this may be a function of low socioeconomic and educational levels of the participants (Araújo et al., 2007; Scheid, 2016).

The majority of these small-scale farmers in this study were male (79\%). It was also observed that a significant portion of the participants reside in rural areas since their childhood and have had intimate contact with agrochemicals for many years. These results have also been reported in other studies that describe the epidemiological profiles of family-based farmers (Viciana, 2015). These results corroborate the hypothesis that the profile of these farmers has changed very little during the last decade, since through dedication to the diverse tasks necessary to keep a small farm functioning, a farmer necessarily comes into frequent contact with agrochemicals. In this context, the farmer is the principal person exposed to the deleterious effects of these substances that are applied to crops and is the most in need of prevention measures to avoid intoxication.

Large-scale agribusiness in general has the objective of exporting production, while smallscale and family-based farmers generally have as an objective supplying the internal market. Even with a high number of officially notified intoxications registered in the public health system, it is believed that there is a high rate of under-notification, either due to an inherent lack of professional medical care, or simply because the small-scale farmer does not seek out this medical care. Through July 2019, the agriculture ministry authorized the registry of 169 additional agrochemicals in the country, among them glyphosate, apparently linked to cancer of immune system cells (Schinasi et al., 2014).

A significant portion of the participants does not properly dispose of the agrochemicals they use and their packing, thus contributing to contamination of the air, soil, and water (Cruz et al., 2017). Another study that used a similar sample size have shown high levels of human and environmental contamination with agrochemicals, and although in the current study trials using doses of agrochemicals applied to the environment by these farmers were not conducted, it can be deduced that there would be a similar correlation with agrochemical use over time and contamination (Araújo et al., 2007).

It is important to note that $23 \%$ of the participants had comorbidities, with the principal ones being HAS and DM. It is possible that this number is underestimated, probably due to not seeking out professional medical assistance or due to inefficiencies and problems inherent to the public health system.

Rev. Ambient. Água vol. 7 (supplement) - Taubaté 2020 


\section{CONCLUSIONS}

This study has shown that, in spite of having a notion of the harmful effects of agrochemicals to health, these small-scale farmers do not regularly use PPEs and underestimate the cumulative damage to their health that can be caused by being constantly exposed to agrochemicals, and also demonstrate a lack of technical knowledge with respect to adequate management of these products. Furthermore, most of these farmers store these products and the empty containers inadequately in their house or in other inappropriate places, thus increasing the risks to their health and to the environment.

\section{REFERENCES}

ARAÚJO, A. J. D.; LIMA, J. S. D.; MOREIRA, J. C.; JACOB, S. D. C.; SOARES, M. D.O.; MONTEIRO, M. C. M. et al. Exposição múltipla a agrotóxicos e efeitos à saúde: estudo transversal em amostra de 102 trabalhadores rurais, Nova Friburgo, RJ. Ciência \& Saúde Coletiva, v. 12, n. 1, p. 115-13, 2007.

BRASIL. Ministério do Meio Ambiente. Segurança química. Available at: http://www.mma.gov.br/seguranca-quimica/agrotoxicos. Access: 20 Jul. 2019.

BRASIL. Presidência da República. Lei n. 4.074, de 04 de janeiro de 2002. Regulamenta a Lei no 7.802 , de 11 de julho de 1989, que dispõe sobre a pesquisa, a experimentação, a produção, a embalagem e rotulagem, o transporte, o armazenamento, a comercialização, a propaganda comercial, a utilização, a importação, a exportação, o destino final dos resíduos e embalagens, o registro, a classificação, o controle, a inspeção e a fiscalização de agrotóxicos, seus componentes e afins, e dá outras providências. Diário Oficial [da] União: seção 1, Brasília, DF, 08 Jan. 2002.

BRASIL. Presidência da República. Lei n. 7.802, de 11 de julho de 1989. Dispõe sobre a pesquisa, a experimentação, a produção, a embalagem e rotulagem, o transporte, 0 armazenamento, a comercialização, a propaganda comercial, a utilização, a importação, a exportação, o destino final dos resíduos e embalagens, o registro, a classificação, o controle, a inspeção e a fiscalização de agrotóxicos, seus componentes e afins, e dá outras providências. Diário Oficial [da] União: seção 1, Brasília, DF, 12 Jul.1989.

CAVALCANTI, L. P. A. N.; AGUIAR, A. P. D.; LIMA, J. A.; LIMA, A. L. S. Intoxicação por organofosforados: Tratamento e metodologias analíticas empregadas na avaliação da reativação e inibição da acetilcolinesterase. Revista Virtual de Química, v. 8, n. 3, 2016. http://dx.doi.org/10.5935/1984-6835.20160056

CERQUEIRA, G. S.; ARRUDA, V. R.; FREITAS, A. P. F. D.; OlIVEIRA, T. L. D.; VASCONCELOS, T. C.; MARIZ, S. R. Dados da exposição ocupacional aos agrotóxicos em um grupo assistido por uma únidade básica de saúde na cidade de Cajazeiras, PB. Revista Intertox de Toxicologia, Risco ambiental e sociedade, v. 3, n. 1, p. 16, 2010.

COSTA, V. I. D. B. D.; MELLO, M. S. D. C. D.; FRIEDRICH, K. Exposição ambiental e ocupacional a agrotóxicos e o linfoma não Hodgkin. Saúde em Debate, v. 41, n. 41, p. 49-62, 2017. https://doi.org/10.1590/0103-1104201711205

CRUZ, A. L. D.; SANTOS, P. A. D.; ZANOTTI, J. Agrotóxicos e Câncer: Correlação entre o uso e o desenvolvimento de neoplasias. In: CONGRESSO DE PESQUISA E EXTENSÃO DA FSG, 5.; SALÃO DE EXTENSÃO, 3., 2017, Caxias do Sul. Anais[...] Caxias do Sul: FSG, 2017. p. 246-248. 
DELGADO, I. F.; PAUMGARTTEN, F. J. R. Intoxicações e uso de pesticidas por agricultores do Município de Paty do Alferes, Rio de Janeiro, Brasil. Cadernos de Saúde Pública, v. 20, n. 1, p. 180-186, 2004. https://doi.org/10.1590/S0102-311X2004000100034

DUTRA, L. S.; FERREIRA, A. P. Associação entre malformações congênitas e a utilização de agrotóxicos em monoculturas no Paraná, Brasil. Saúde em Debate, v. 41, n. 2, p. 241253, 2017. https://doi.org/10.1590/0103-11042017S220

HUNGARO, A. A.; CORREIA, L. M.; SILVINO, M. C. S.; ROCHA, S. M.; MARTINS, B. F.; OLIVEIRA, M. L. F. de. Intoxicações por agrotóxicos: Registro de um serviço sentinela de assistência toxicológica. Ciência, Cuidado e Saúde, v. 14, n. 3, p. 1362-1369, 2015. https://doi.org/10.4025/cienccuidsaude.v14i3.25119

LEMES, V. R. R.; BARRTTO, H. H. C.; KUSSUMI, T. A.; COLACIOPPO, S. Avaliação de resíduos de ditiocarbamatos e etilenotiouréia (ETU) em mamão e sua implicação na saúde pública. Revista do Instituto Adolfo Lutz, v. 64, n. 1, p. 50-57, 2005.

MYERS, P. J.; ANTONIOU, M. N.; BLUMBERG, B.; CARROLL, L.; COLBORN, T.; EVERETT, L. G. et al. Concerns over use of glyphosate-based herbicides and risks associated with exposures: a consensus statement. Environmental Health, v. 15, n. 19, p. 1-13, 2016. https://doi.org/10.1186/s12940-016-0117-0

NASCIMENTO, L.; MELNYK, A. A química dos pesticidas no meio ambiente e na saúde. Revista Mangaio Acadêmico, v. 1, n. 1, p. 54-61, 2016.

OSSOWSKA, K.; ŚMIAŁOWSKA, M.; KUTER, K.; WIEROŃSKA, J.; ZIĘBA, B.; WARDAS, J. et al. Degeneration of dopaminergic mesocortical neurons and activation of compensatory processes induced by a long-term paraquat administration in rats: Implications for Parkinson's disease. Neuroscience, v. 141, n. 4, p. 2155-2165, 2006. https://doi.org/10.1016/j.neuroscience.2006.05.039

RODRIGUES, M. L. N.; SERRA, G. Determinação de resíduos de 2,4D em amostras vegetais. Pesticidas: Revista de Ecotoxicologia e Meio Ambiente, v. 6, p. 99-104, 1996. http://dx.doi.org/10.5380/pes.v6i0.39458

SCHEID, M. W. Percepção dos agricultores do município de Cerro de Largo/RS sobre a exposição a agrotóxicos em sua atividade ocupacional. 2016. 56f. TCC (Graduação em Ciências biológicas) - Universidade Federal da Fronteira Sul, Cerro Largo, 2016.

SCHINASI, L.; LEON, M. E. Non-Hodgkin Lymphoma and Occupational Exposure to Agricultural Pesticide Chemical Groups and Active Ingredients: A Systematic Review and Meta-Analysis. International Journal of Environmental Research and Public Health, v. 11, n. 4, p. 4449-4527, 2014. https://doi.org/10.3390/ijerph110404449

SILVA, A. C. D.; CAMPONOGARA, S.; VIERO, C. M.; MENEGAT, R. P.; DIAS, G. L. MIORIN, J. D. Perfil socioeconômico de Trabalhadores Rurais portadores de neoplasias. Revista Online de Pesquisa: Cuidado é fundamental, v. 8, n. 3, p. 4891-4897, 2016. https://dx.doi.org/10.9789/2175-5361.2016.v8i3.4891-4897

SISTEMA NACIONAL DE INFORMAÇÕES TÓXICO-FARMACOLÓGICAS. Webpage. 2018. Available at: https://sinitox.icict.fiocruz.br/. Access: 22 Jul. 2019. 
VICIANA, R. S. Perfil epidemiológico dos trabalhadores avaliados no programa de atenção à saúde de populações expostas a agrotóxicos da Unicamp entre 2003 e 2012. Repositório da Produção Científica e Intelectual da Unicamp. 2015. Available at: http://repositorio.unicamp.br/jspui/handle/REPOSIP/312501. Access: 22 Jul. 2019.

VIEIRA, M.; PRADO, A. G. S. D.; LANDGRAF, M. D.; REZENDE, M. O. de O. Estudo da adsorção / dessorção do ácido 2,4 diclorofenoxiacético $(2,4 \mathrm{D})$ em solo na ausência e presença de matéria orgânica. Química Nova, v. 22, n. 3, p. 305-308, 1999.

VIERO, C. M.; CAMPONOGARA, S.; CEZAR-VAZ, M. R.; COSTA, V. Z. D.; BECK, C. L. C. Sociedade de risco: o uso dos agrotóxicos e implicações na saúde do trabalhador rural. Rede de Revistas Científicas da América Latina, Caribe , Espanha e Portugal, v. 20, n. 1, p. 99-105, 2016. https://doi.org/10.5935/1414-8145.20160014 